\title{
Sciendo
}

\section{CD63 AND DNA MISMATCH REPAIR PROTEIN EXPRESSION IN PROSTATE CANCER}

\author{
Kristofs Folkmanis ${ }^{1,2, \#, ~ J a ̄ n i s ~ E g l i ̄ t i s ~}{ }^{1,3}$, Māris Jakubovskis ${ }^{3,4}$, Vilnis Lietuvietis ${ }^{3,4}$, \\ Inese Folkmane ${ }^{1}$, and Sergejs Isajevs ${ }^{1,3}$ \\ ${ }^{1}$ Faculty of Medicine, University of Latvia, 3 Jelgavas Str., Rīga, LV-1004, LATVIA \\ 2 St. Bonifatius Hospital, Lingen (Ems), 13 Wilhelm Str., Lingen, 49808, GERMANY \\ ${ }^{3}$ Rīga East University Clinical Hospital, 2 Hipokrāta Str., Rīga, LV-1038, LATVIA \\ ${ }^{4}$ Rīga Stradiṇš University, 16 Dzirciema Str., Rīga, LV-1007, LATVIA \\ \# Corresponding author, kristofs87@inbox.lv
}

Communicated by Ingrīda Rumba-Rozenfelde

\begin{abstract}
Protein expression levels in immunohistochemistry and molecular biomarkers have been reported for their ability to predict recurrence, progression, development of metastases, and patient survival. The molecular features in low- and high-grade prostate cancer can differ and influence treatment decision and prognosis. The objective of the current study was to compare the expression of exosomal biomarkers CD63 and mismatch repair proteins (MSH2, MSH6, MLH1, and PMS2) by immunohistochemistry (IHC) in tissue of patients with prostate cancer and benign hyperplasia. Altogether, 62 patients with prostate acinar adenocarcinoma and 20 patients with prostate benign hyperplasia were enrolled in this retrospective study. CD63, MSH2, MSH6, MLH1, and PMS2 expression was analysed by immunohistochemistry. The obtained results showed that CD63 expression was significantly higher in patients with Grade III-V prostate cancer compared to Grade I-II, respectively; $2.23(1-3)$ vs 0.92 (0-2) score, $\mathrm{p}=0.001$. In addition, a significant positive correlation between CD63 expression and grade groups was revealed ( $R$ ho $=+0.54 ; p<$ 0.0001). Furthermore, progression-free survival was significantly higher in patients with low CD63 expression, compared to high CD63 expression $(\mathrm{p}=0.0007)$. MMR expression was absent in 14 patients (four patients with Grade I-II cancer and 10 patients with Grade III-cancer). MMR was present in all cases of benign prostate hyperplasia (mild to moderate staining). The conclusion was that high grade prostate cancer (Grade groups III-V) was characterised by increased CD63 expression, which correlated with progression-free survival.
\end{abstract}

Keywords: CD63 exosomal biomarker, mismatch repair protein biomarkers, mismatch repair pathway deficiency, immunohistochemistry, prostate acinar adenocarcinoma, benign prostate hyperplasia.

\section{INTRODUCTION}

Prostate cancer (PCa) remains the second most commonly diagnosed cancer in men, with an estimated 1.1 million diagnoses worldwide in 2012, accounting for $15 \%$ of all cancers diagnosed (Jahn et al., 2015; Siegel et al., 2019).

The Gleason score and Gleason grade groups are assigned by pathologists based on prostate cancer morphology to describe the loss of tissue structure and order, which are strongly correlated with disease aggressiveness and patient outcome. The Gleason grade is determined by pathologists based on the architectural growth patterns of the tumour in hematoxylin and eosin (H\&E) stained tissue specimens (Siegel et al., 2019).

Gleason scoring categorises tumour tissue into patterns from 1 (low risk) to 5 (high risk). Therefore, Gleason score Grade groups have long been recognised as being strongly associated with risk of prostate cancer recurrence and metastasis (Siegel et al., 2019).

In many cases, successful treatment of prostate cancer is difficult due to the late detection and rate of metastasis (Kim and Kim, 2011). Importantly, the tumours of many patients with prostate cancer become refractory to androgen 
therapy and progress to metastatic castration-resistant disease (Ingrosso et al., 2018).

An effective treatment course of prostate cancer patients requires predictive biomarkers in metastatic castration-resistant prostate cancer that support individual therapy (Kretschmer and Tilki, 2017).

Different risk classification tools have been developed to distinguish patients with early $\mathrm{PCa}$ according to the prognosis, including the D'Amico classification system, the Cancer of the Prostate Risk Assessment score, and the National Comprehensive Cancer Network (NCCN) risk groups classification (D'Amico et al., 2000; Kretschmer and Tilki, 2017; Braitbord et al., 2017; Filela et al., 2018). All these systems recognise a low risk of progression for patients with a biopsy Gleason score $\leq 6$.

Liquid biopsies, circulating tumour cells, exosomes and circulating nucleic acids have been developed as minimally invasive assays to monitor PCa patients (Cullen et al., 2015).

Furthermore, a four-kallikrein panel comprised of total PSA, fPSA, iPSA has been proposed for risk stratification of disease progression (Filella et al., 2018).

In addition, novel tissue-based genomic biomarkers have been used to help in the post-biopsy decision, offering additional information in risk stratification, aiding to personalise therapies (Blume-Jensen et al., 2015; Cullen et al., 2015).

Exosomes are membranous nanovesicles (extracellular vesicles (EVs) with 30-150 nm diameter) of endocytic origin and are secreted by most cell types from diverse organisms. Depending on the cell of origin and the conditions for secretions, exosomes appear to contribute to a diverse range of biological processes and play a pivotal role in mediating intercellular and distant communication by transferring various functional biomolecules including RNAs, DNA, lipids, and proteins (Lu et al., 2019).

Exosomal membranes are enriched in endosome-specific tetraspanins (CD9, CD63, CD81) (Lu et al., 2019). They have been shown to carry a variety of lipids, proteins, mRNAs and non-coding RNAs that can be taken up by recipient cells, where they trigger intracellular signalling resulting in diverse physiological and pathological responses (Pant et al., 2012).

Currently there is great interest in understanding the role of exosomes in cancer progression, including of prostate cancer (PCa), and whether exosomes could be used as a potential source of biomarkers in PCa (Azmi et al., 2013; Soekmedji et al., 2013).

Exosomes have been shown to be crucial for the development of drug resistance in patients with prostate tumour (Tarhan et al., 2005). Exosome-derived microRNAs also contribute to $\mathrm{PCa}$ chemoresistance and can act as surrogate biomarkers of tumour response to taxanes (Kharaziha et al., 2015; Del Re et al., 2017).
The value of exosomal biomarkers CD63 and CD9 in patients with prostate carcinoma in blood serum, plasma and urine has been previously demonstrated and the significant correlation of disease prognosis with the level of exosomes in blood plasma has been observed (Tarhan et al., 2005; Thompson, 2006; Azmi et al., 2013; Soekmadji et al., 2013; Kharaziha et al., 2015; Del Re et al., 2017). However, the expression of exosomal biomarkers in the tissue assessed by immunohistochemical is still poorly understood.

Failure of effective DNA damage repair is a hallmark of cancer. The mismatch repair (MMR) pathway recognises and repairs insertions, deletions and base-base mismatches that occur on single-stranded DNA during replication ( $\mathrm{Li}$, 2007; Pritchard et al., 2014). However, previous studies showed that the prevalence of mismatch repair pathway deficiency in prostate cancer cases is about $15 \%$ (Kretschmer and Tilki, 2017). The most commonly altered MMR genes are MSH2 and MSH6, which can be inactivated by intronic structural rearrangements that are undetectable by exonlimited sequencing approaches (Pritchard et al., 2014).

However, it is not yet clear whether MMR defects are enriched in metastatic disease relative to localised disease.

A recent study of MSH2 protein expression in 1133 primary prostatic adenocarcinomas identified its loss in $1.1 \%$ of cases, which is similar to metastatic disease, but it was significantly enriched in Gleason score 9-10 tumours, which implies an association with disease progression (Pritchard et al., 2014; Guedes et al., 2017).

The aim of our study was to evaluate the expression of CD63 and DNA mismatch proteins (MMR)-MSH2, MSH6, MLH1, and PMS2 by immunohistochemistry in patients with prostate benign hyperplasia and adenocarcinoma tissue and their influence on progression-free survival.

\section{PATIENTS AND METHODS}

The study was retrospective. Altogether, 62 patients with prostate acinar adenocarcinoma who underwent radical prostatectomy and 20 patients who underwent fine needle biopsy with prostate benign hyperplasia during 2013-2015 were enrolled in the study.

The study was performed in accordance with the Declaration of Helsinki. The study was approved by the Ethics Committee of Institute of Cardiology and Regenerative Medicine, Rīga, Latvia. Tissue samples were collected from the Biobank of Riga East University Hospital and the Institute of Clinical and Preventive Medicine, University of Latvia. All patients gave written consent to participate in scientific research.

Histology. The histopathological evaluation of prostate cancer tissue was performed according to the guidelines of the current WHO classification of Tumours of the Urinary System and Male Genital Organs and CAP (College of American Pathologist) prostata cancer protocol. Briefly, the 
tumour type, Gleason grading, grade group and cancer invasiveness were assessed.

The tumour TNM staging was performed according to the 8th AJCC (American Joint Committee on Cancer) Cancer Staging Manual.

Tissue processing and immunohistochemistry. Paraffinembedded tissue specimens were retrieved from the Biobank of Rīga East University Hospital. Specimens were

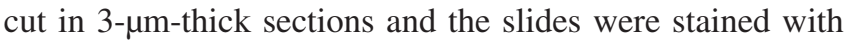
haematoxylin and eosin to evaluate histopathological changes. Antigen retrieval was achieved by incubating the slides with Tris/EDTA buffer at $\mathrm{pH}=9.0$ for $30 \mathrm{~min}$ in a scientific microwave. The slides were then incubated overnight at $4{ }^{\circ} \mathrm{C}$ with mouse monoclonal CD63 (AbCam, ab, ab215891, rabbit monoclonal MSH2 (AbCam, ab227941, dilution 1 : 500), rabbit monoclonal MSH6 (AbCam, ab273076), rabbit monoclonal MLH1 (AbCam, ab23844, dilution 1 : 500), and rabbit monoclonal PMS2 (AbCam, ab110630, dilution $1: 100$. Antibody binding was detected using the EnVision reagent following the manufacturer's instructions (DAKO).

Immunostained slides of each histology sample were scanned with a Pannoramic Midi slide scanner (3D Histech Hungary) at magnification $\times 20$. The whole area of each slide scanned was analysed using an Image Analysis QuantCenter (3DHistech).

CD63, MSH2, MSH6, MLH1, and PMS2 expression was evaluated by intensity of staining and percentage of stained cancer cells and stromal cells respectively: intensity was given scores $0-3(0=$ no, $1=$ weak, $2=$ moderate, $3=$ intense), and the percentage of immunopositive cells for CD63 was given scores $0-3(0=0 \%, 1=10 \%, 2=20-30 \%$, $3=40-100 \%)$.

Statistical analysis. Values were expressed as means (range). The Fisher exact test or chi-square test was used to evaluate the association between categorical variables.

Associations between CD63, MSH2, MSH6, MLH1, and PMS2 expression and clinicopathological findings were analysed using the chi-square test. Overall survival (OS) was defined as the time from operation to death from any cause. OS curves were estimated by the Kaplan-Meier method and compared using the log-rank test. Multivariate analysis was carried out using the Cox proportional hazard model. $p$ values less than 0.05 were considered to be statistically significant. SPSS 21. version software was used for the statistical analysis.

\section{RESULTS}

Overall clinical characteristics. Table 1 demonstrates the general characteristics of patients. Altogether, 82 patients were enrolled in the study. 62 patients had prostate acinar adenocarcinoma and 20 patients had benign prostate hyperplasia.
Table 1. Characteristics of patients with prostate cancer

\begin{tabular}{lc}
\hline \multicolumn{1}{c|}{ Age } & $64.5(43-85)$ years \\
\hline Grade group I & 22 patients \\
Grade group II & 10 patients \\
Grade group III & 12 patients \\
Grade group IV & 10 patients \\
Grade group V & 8 patients \\
pT2 & 48 patients \\
pT3a & 10 patients \\
pT3b & 4 patients \\
pN0 & 54 patients \\
pN1 & 8 patients
\end{tabular}

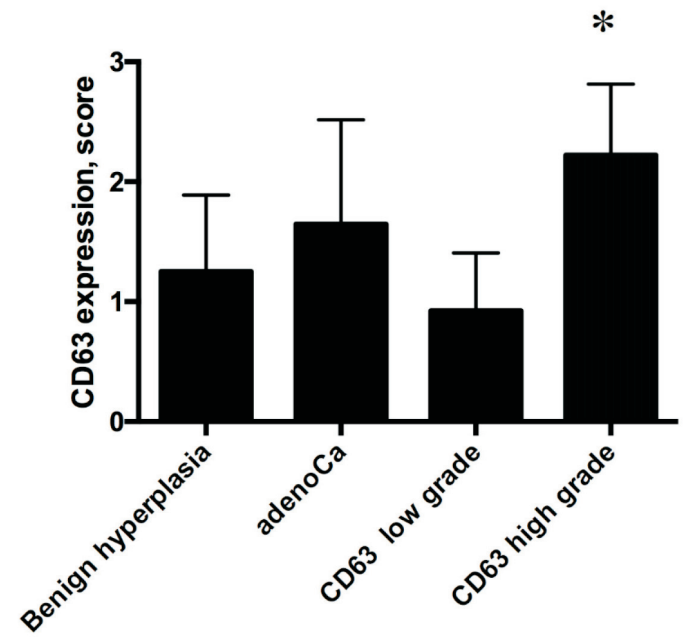

Fig. 1. CD63 expression in prostate benign hyperplasia, acinar adenocarcinoma and low-risk (Grade groups I-II) and high-risk (Grade groups III-V) prostate acinar adenocarcinoma, $p=0.03$, compared high-risk to low-risk adenocarcinoma. The Chi-square test was used.

The median age of the study subjects with prostate cancer and benign hyperplasia was 64.5 (43-85). Low-grade prostate cancer (Grade groups I and II) was observed in 32 patients, and high-grade cancer (Grade groups III-V) was observed in 30 patients with acinar adenocarcinoma.

CD63 expression in prostate tissue. The obtained results showed that there was no difference in CD63 expression between benign prostate hyperplasia and prostate carcinoma (1.25 (0-2) vs. 1.64 (0-3), score).

However, when the low and high risk patients were independently analysed, CD63 expression was significantly higher in patients with Grade III-V prostate cancer compared to Grade I-II prostate cancer, respectively, 2.23 (1-3) vs 0.92 (0-2) score, $p=0.001$ (Fig. 1).

In addition, there was a significant positive correlation between CD63 expression and grade group $(\mathrm{Rho}=+0.54 ; p<$ $0.0001)$

MMR expression was absent in ten patients (two patients with Grade group III, five patients with Grade group IV and three patients with Grade group V. 
The Kaplan-Meier method using the log-rank test demonstrated that the progression-free survival was significantly higher in patients low CD63 expression (score 0 and 1), compared to high CD63 expression (scores 2 and 3) (Fig. 2).

A representative photomicrograph of CD63 expression in patients with benign prostate hyperplasia and prostate acinar adenocarcinoma is shown in Figure 3.

MSH2, MSH6, MLH1, and PMS2 expression in prostate tissue. MMR was present in all cases of benign prostate hyperplasia (mild to moderate staining).

Immunohistochemically staining for 4 MMR proteins was conducted.

Overall, MLH1, MSH2, MSH6, and PMS2 loss occurred in $10(16 \%), 12(19 \%), 8(13 \%)$, and $14(22 \%)$ prostate cancers, respectively. All cases with MLH1 loss concurrently occurred with loss of three other proteins, while all cases with MSH2 loss showed concurrent MSH6 loss.

Thus, the loss of at least 1 MMR protein was identified in $14(22 \%)$ cases; from these patients nine patients had Grade III-V cancer and five patients had Grade I-II cancer.

The study revealed negative correlation between loss of MMR proteins and grade group, Rho $=-0.43 ; p=0.0005$ ).

\section{DISCUSSION}

Prostate cancer is one of the most common malignancies in developed countries and the second cause of cancer death

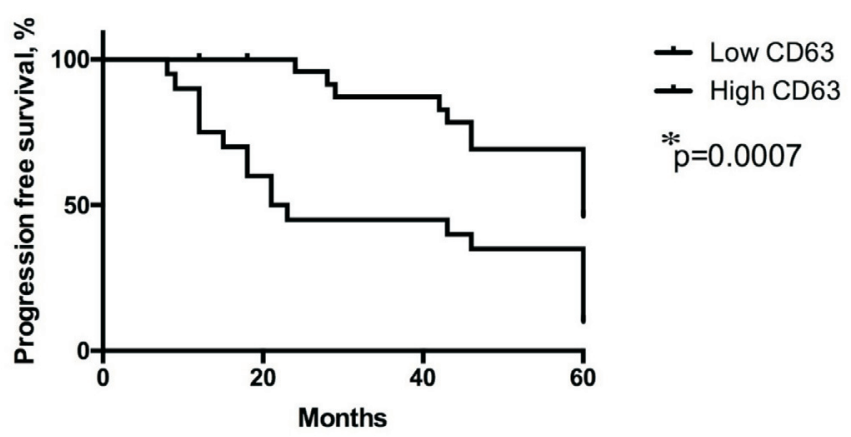

Fig. 2. Progression-free survival of prostate cancer with low CD63 and high CD63 expression. The Kaplan-Meier method using the log-rank test was used.
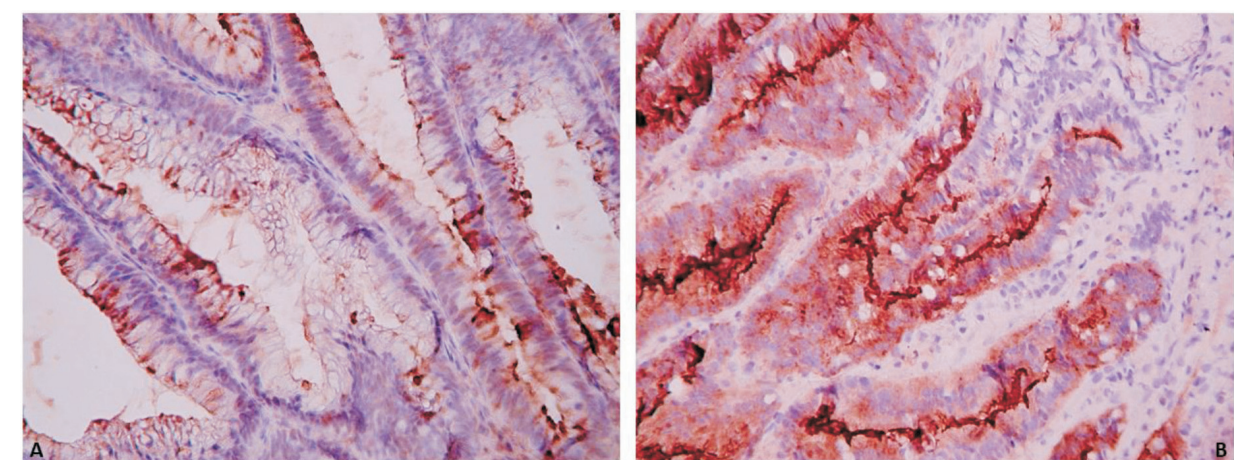

for men (Siegel et al., 2019). A large proportion of prostate cancer (PCa) cases are latent, which never destined to progress to metastatic disease. It is of utmost importance to identify which PCa are destined to progress and which would benefit from an early radical treatment. The prostatespecific antigen (PSA) remains the most used test to detect PCa. Its limited specificity and an elevated rate of overdiagnosis are the main problems associated with PSA testing.

The classic prostate cancer predictive criteria, which stratify the risk of disease progression, are histopathological criteria like cancer histopathological subtype, Gleason grading system, and Grade groups, which are assessed in prostate biopsy samples by a pathologist.

In the past decade, advances in precision oncology have resulted in an increased demand for predictive assays that enable risk stratification for prognosis and risk stratification for disease progression (Tarhan et al., 2005; Thompson, 2006; Azmi et al., 2013; Soekmadji et al., 2013; Kharaziha et al., 2015; Del Re et al., 2017).

Approximately $10 \%$ of advanced/metastatic prostate tumours have a markedly elevated rate of single nucleotide mutations, almost always due to underlying somatic and/or germline inactivation of genes in the mismatch repair (MMR) family (MSH2, MSH6, MLH1 or PMS2) and often accompanied by microsatellite instability (MSI) (Guedes et al., 2017).

Our study demonstrated loss of MMR expression in $18 \%$ of low-risk prostate cancer and $25 \%$ of high risk prostate cancer cases. In addition, correlation of loss of MMR expression and Grade groups was revealed in our study.

Only a few immunohistochemical studies have reported the incidence of MMR deficiency in prostate cancer, with ranges from 1.2 to to $22.7 \%$ (Guedes et al., 2017; AlberoGonzález et al., 2019; Sharma et al., 2020).

MSH2 loss was significantly more often seen in tumours with Gleason score 9-10/Grade Group V than in those with Gleason score $\leq$ 8/Grade Group $\leq$ IV (Miki et al., 2018). In contrast, other studies did not demonstrate significant associations between MLH1/MSH2/PMS2 loss and Gleason and grade groups (Albero-González et al., 2019; Sharma et al., 2020).

Fig. 3. Representative photomicrograph of CD63 expression in patients with benign prostate hyperplasia (A) and prostate acinar adenocarcinoma (B). Immunohistochemical staining method, magnification $\times 400$. 
Recently, it has been reported that exosomes from cancer cells might be associated in intracellular communication involved in the development of the tumour microenvironment, such as metastatic niche formation and angiogenesis, resulting in the progression of carcinoma (Boucheix et al., 2001).

In this study, we found that CD63 expression in prostate cancer was an independent significant prognostic factor. As CD63 is a surface marker of exosomes, our data might suggest that exosomes derived from prostate cancer cells play an important role in cancer progression. To the best of our knowledge, this is the first study to investigate the clinicopathological significance of exosome marker CD63 expression in prostate cancer tissue assessed by immunohistochemistry.

It has been demonstrated that positive areas for prostatespecific membrane antigen (PSMA) were significantly different in patients with benign prostate hyperplasia (BPH), and low-risk, intermediate-risk, and high-risk PCa, shown using transmission electron microscope (TEM) with immunoperoxidase/diaminobenzidine (DAB) methods and immunogold enhancement and immunofluorescence imaging (Park et al., 2016). In addition, analysis of prostatic tissue by confocal microscopy showed a punctate pattern of colocalised CD63 (green) and PSMA (red), confirming the TEM results (Park et al., 2016). However, plasma CD63positive EV concentration did not significantly differ among patients with different disease status.

Previous studies showed that urinary exosomes markers can aid in the decision-making process regarding whether to carry out a prostate biopsy and in the design of a therapeutic strategy (Fujita and Nonomura, 2018). Urinary exosomes and their cargo, especially miR-21 and miR-375, have become an emerging source of biomarkers in the detection and prognosis of PCa (Foj et al., 2017). Moreover, the expression of serum exosomal miRNAs induced by radiotherapy may have potential value as prognostic and predictive biomarkers PCa (Soekmadji, 2013).

It has been observed that after DRE and correction for urinary PSA, CD9 and CD63 were significantly higher in men with prostate cancer (Duijbesz et al., 2015).

One of potential surrogate methods to detect exosomes in the tissue is the immunohistochemical method. There are only a few studies that used immunohistochemistry to investigate the role of exosomales biomarkers in prostate tissue.

It has been previously shown that CD9 expression is significantly reduced and even lost during prostate cancer progression. Moreover, deletions and mutations of CD9 mRNA may be associated with loss of protein expression observed in tumour cells. Our data suggest that CD9 inactivation may play an important role in prostate cancer progression.

Furthermore, CD9 was observed to be well expressed in nonmetastatic disease but less expressed or absent in meta- static prostate (Thompson, 2006). However, there are no data in the literature about using immunohistochemistry to examine CD63 biomarker expression in prostate cancer tissue. However, CD63 expression by immunohistochemistry has been demonstrated in other human cancer types.

In pancreatic cancer, the expression of CD63 has been reported to be higher in cancerous tissue than in normal tissue (Khushman et al., 2017). In addition, it was shown that CD63 expression in gastric cancer cells was a significant independent prognostic factor in patients with gastric cancer (Miki et al., 2018).

Our study demonstrated by immunohistochemical examination of prostate tissue that CD63 expression was significantly higher in patients with Grade III-V prostate cancer compared to Grades I-II. In addition, the significant positive correlation between CD63 expression and grade group was revealed. Furthermore, the progression-free survival was significantly higher in patients with low CD63 expression, compared to high CD63 expression.

In conclusion, CD63 tissue immunohistochemical detection might be a prognostic marker for patients with prostate cancer. CD63-positive exosomes are associated with the malignant potential of cancer cells through the interaction between stromal cells and cancer cells.

Routine immunohistochemical staining for CD63 in primary prostate cancer tissue in clinical practice could be beneficial and cost-effective for the risk stratification of disease progression.

\section{REFERENCES}

Albero-González, R., Hernández-Llodrà, S., Juanpere, N. (2019). Immunohistochemical expression of mismatch repair proteins (MSH2, MSH6, MLH1, and PMS2) in prostate cancer: Correlation with grade groups (WHO 2016) and ERG and PTEN status. Virchows Arch., 475, 223-231.

Azmi, A. S., Bao, B., Sarkar, F. H. (2013). Exosomes in cancer development, metastasis, and drug resistance: A comprehensive review. Cancer Metastasis Rev., 32 (3-4), 623-642.

Blume-Jensen, P., Berman, D. M., Rimm, D. L. (2015). Development and clinical validation of an in situ biopsy-based multimarker assay for risk stratification in prostate cancer. Clin. Cancer Res., 21 (11), 2591-2600.

Boucheix, C., Duc, G. H., Jasmin, C., Rubinstein, E. (2001) Tetraspanins and malignancy. Expert Rev. Mol. Med., 2001, 1-17.

Brajtbord, J. S., Leapman, M. S., Cooperberg, M. R. (2017). The CAPRA score at 10 years: Contemporary perspectives and analysis of supporting studies. Eur. Urol., 71 (5), 705-709.

Cullen, J., Rosner, I. L., Brand, T. C. (2015). A biopsy-based 17-gene genomic prostate score predicts recurrence after radical prostatectomy and adverse surgical pathology in a racially diverse population of men with clinically low- and intermediate-risk prostate cancer. Eur. Urol., 68 (1), 123-131.

D'Amico, A. V., Whittington, R., Malkowicz, S. B. (2000). Clinical utility of the percentage of positive prostate biopsies in defining biochemical outcome after radical prostatectomy for patients with clinically localized prostate cancer. J. Clin. Oncol., 18 (6),1164-1172.

Del Re, M., Biasco, E., Crucitta, S., Derosa, L., Rofi, E., Orlandini, C., Miccoli, M., Galli, L., Falcone, A., Jenster, G. W. (2017). The detection of androgen receptor splice Variant 7 in plasma-derived exosomal RNA 
strongly predicts resistance to hormonal therapy in metastatic prostate cancer patients. Eur. Urol., 71, 680-687.

Duijvesz, D., Versluis, C. Y., van der Fels, C. A., Vredenbregt-van den Berg, M. S., Leivo, J., Peltola, M. T., Bangma, C. H., Pettersson, K. S. I., Jenster, G. (2015). Immuno-based detection of extracellular vesicles in urine as diagnostic marker for prostate cancer. Int. J. Cancer, 137, 2869-2878.

Filella, X., Fernández-Galan, E., Bonifacio, R. F., Foj, L. (2018). Emerging biomarkers in the diagnosis of prostate cancer. Pharmgenomics Pers. Med., 11, 83-94.

Foj, L., Ferrer, F., Serra, M., Arevalo, A., Gavagnach, M., Gimenez, N., Filella, X. (2017). Exosomal and non-exosomal urinary miRNAs in prostate cancer detection and prognosis. Prostate. 77, 573-583.

Fujita, K., Nonomura, N. (2018). Urinary biomarkers of prostate cancer. Int. J. Urol., 25, 770-779.

Guedes, L. B., Antonarakis, E. S., Schweizer, M. T. (2017). MSH2 loss in primary prostate cancer. Clin. Cancer Res., 23, 6863-6874.

Ingrosso, G., Detti, B., Scartoni, D., Lancia, A., Giacomelli, I., Baki, M., Carta, G., Livi, L., Santoni, R. (2018). Current therapeutic options in metastatic castration-resistant prostate cancer. Semin. Oncol., 45, 303-315.

Jahn, J. L., Giovannucci, E. L., Stampfer, M. J. (2015). The high prevalence of undiagnosed prostate cancer at autopsy: Implications for epidemiology and treatment of prostate cancer in the prostate-specific antigen-era. Int. J. Cancer, 137 (12), 2795-2802.

Kharaziha, P., Chioureas, D., Rutishauser, D., Baltatzis, G., Lennartsson, L., Fonseca, P., Azimi, A., Hultenby, K., Zubarev, R., Ullen. A. (2015). Molecular profiling of prostate cancer derived exosomes may reveal a predictive signature for response to docetaxel. Oncotarget, 6, 21740-21754.

Khushman, M., Bhardwaj, A., Patel, G. K., Laurini, J. A., Roveda, K., Tan, M. C., Patton, M., Singh, S., Taylor, W., Singh, A. P. (2017). Exosomal markers (CD63 and CD9) expression pattern using immunohistochemistry in resected malignant and nonmalignant pancreatic specimens. Pancreas, 46, 782-788.

Kim, S. J., Kim, S. I. (2011). Current treatment strategies for castration-resistant prostate cancer. Korean J. Urol., 52, 157-165.

Kretschmer, A., Tilki, D. (2017). Biomarkers in prostate cancer: Current clinical utility and future perspectives. Crit. Rev. Oncol. Hematol., 120,180-193.

Li, G.-M. (2007). Mechanisms and functions of DNA mismatch repair. Cell Res., 18, 85-98.

Received 2 November 2020

Accepted in the final form 14 January 2021
Lu, Y. T., Delijani, K., Mecum, A., Goldkorn, A. (2019). Current status of liquid biopsies for the detection and management of prostate cancer. Cancer Manag. Res., 11, 5271-5291.

Malla, B., Aebersold, D. M., Pra, A. D. (2018). Protocol for serum exosomal miRNAs analysis in prostate cancer patients treated with radiotherapy. $J$. Transl. Med. 16, 223.

Miki, Y., Yashiro, M., Okuno, T., Kuroda, K., Togano, S., Hirakawa, K., Ohira, M. (2018). Clinico-pathological significance of exosome marker CD63 expression on cancer cells and stromal cells in gastric cancer. PLoS One, 13 (9), e0202956.

Moch, H., Humphrey, P. A., Ulbright, T. M., Reuter, V. E. (eds.) (2016). WHO Classification of Tumours of the Urinary System and Male Genital Organs. WHO Classification of Tumours, 4th Edition, Volume 8. WHO. 400 pp.

Pant, S., Hilton, H., Burczynski, M. E. (2012). The multifaceted exosome: Biogenesis, role in normal and aberrant cellular function, and frontiers for pharmacological and biomarker opportunities. Biochem. Pharmacol., 83 (11), 1484-1494

Park, Y. H., Shin, H. W., Jung, A. R., Kwon, O. S., Choi, Y.-J., Park, J., Lee, J. Y. (2016). Prostate-specific extracellular vesicles as a novel biomarker in human prostate cancer. Sci. Rep., 6, 30386.

Pritchard, C. C., Morrissey, C., Kumar, A. (2014) Complex MSH2 and MSH6 mutations in hypermutated microsatellite unstable advanced prostate cancer. Nat. Commun., 5, 4988.

Sharma, M., Yang, Z., Miyamoto, H. (2020). Loss of DNA mismatch repair proteins in prostate cancer. Medicine (Baltimore). 99 (19), e20124.

Siegel, R. L., Miller, K. D., Jemal, A. (2019). Cancer statistics, 2019. CA Cancer J. Clin. 69, 7-34.

Soekmadji, C., Russell, P. J., Nelson, C. C. (2013). Exosomes in prostate cancer: Putting together the pieces of a puzzle. Cancers (Basel), 5 (4), 1522-1544.

Tarhan, F., Orcun, A., Kucukercan, I., Camursoy, N., Kuyumcuoglu, U. (2005). Effect of prostatic massage on serum complexed prostate-specific antigen levels. Urology, 66, 1234-1238.

Thompson, I. M. (2006). PSA: A biomarker for disease. A biomarker for clinical trials. How useful is it? J. Nutr., 136, 2704 S.

Wang, J. C., Louis, R., Bégin, N. G., Chevalier, B. S. Aprikian, A. G., Gourdeau, H., Chevrette, M. (2007). Down-regulation of CD9 expression during prostate carcinoma progression is associated with CD9 mRNA modifications. Clin. Cancer Res., 13 (8), 2354-2356.

\section{CD63 UN DNS NESAKRITĪBAS LABOJOŠO PROTEĪNU EKSPRESIJA PACIENTIEM AR PROSTATAS VĒZI}

Tiek ziṇots, ka ar olbaltumvielu ekspresijas līmeṇu noteikšanu imūnhistokīmijā un molekulārajos biomarḳieros ir iespējams prognozēt slimības recidīvu, progresēšanu, metastāzēšanos un pacienta dzīvildzi. Zemas un augstas pakāpes prostatas vēža molekulārās īpatnības varētu atškirties ārstēšanas lēmuma pieṇemšanā un prognozē. Pētījuma mērkiis bija salīdzināt eksosomu biomarkieru CD63 un nesakritības labojošo proteīnu (MSH2, MSH6, MLH1 un PMS2) ekspresiju ar imūnhistokīimijas metodi pacientu, kam ir prostatas vēzis un labdabīga prostatas hiperplāzija, audos. Kopumā šajā retrospektīvajā pētījumā tika iekḷauti 62 pacienti ar prostatas acināru adenokarcinomu un 20 pacienti ar prostatas labdabīgu hiperplāziju. CD63, MSH2, MSH6, MLH1 un PMS2 ekspresija tika analizēta ar imūnhistokīmijas metodi. Iegūtie rezultāti parādīja, ka, salīdzinot ar 1.-2. pakāpes prostatas vēzi, CD63 ekspresija bija ievērojami augstāka pacientiem ar 3.-5. pakāpes prostatas vēzi - attiecīgi 2,23 (1-3) pret 0,92(0-2), $p=0,001$. Turklāt tika atklāta nozīmīga pozitīva korelācija starp CD63 ekspresiju un vēža pakāpes grupām (Rho $=+0,54 ; \quad p<0,0001)$. Arī dzīvildze bez slimības progresēšanas bija ievērojami augstāka pacientiem ar zemu CD63 ekspresiju, salīdzinot ar augstu CD63 ekspresiju ( $p=0,0007)$. MMR ekspresija nebija vērojama 14 pacientiem (četriem pacientiem ar 1.-2. pakāpes vēzi un desmit pacientiem ar 3. pakāpes vēzi). MMR ekspresija bija visos labdabīgas prostatas hiperplāzijas gadījumos (viegla vai mērena krāsošanās). Secinājums: augstas pakāpes prostatas vēzis (3.-5. pakāpes grupas), kam raksturīga paaugstināta CD63 ekspresija, korelēja ar dzīvildzi bez slimības progresēšanas. 